of the Essential Oil on the Antioxidant Protection of Saccharomyces cerevisiae Model Organism. Antioxidants, 3 (1), 81-98. doi: https://doi.org/10.3390/antiox3010081

[8] Tykhonenko, N. I., Kotov, A. G. (2010). To the matter of introduction to the State Pharmacopoeia of Ukraine of the monograph «Thyme». Farmakom, 4, 31-38.

[9] Markovych, I. I., Paska, M. Z. (2015). Impact of raw materials on the fatty acid profile changes of semi-smoked sausages. Naukovyi visnyk Lvivskoho natsionalnoho universytetu veterynarnoi medytsyny ta biotekhnolohiyi imeni S. Z. Gzhytskoho, 4 (64), 71-75.

[10] Paska, M., Simonova, I., Galuch, B., Basarab, I., Masliichuk, O. (2017). Toxic elements in lentil, thyme and juniper in the composition of semi-smoked sausages using the method of atomic-absorption spectrometry with atomization in flame. EUREKA: Life Sciences, 4, 35-42. doi: https://doi.org/10.21303/25045695.2017.00388

[11] Mozhzhevel'nik - ohotnich'ya pryanost' (2010). Myasnoe delo, 7, 33.

\title{
DETERMINATION METHODS OF DEFROSTED PROTEIN-VEGETABLE MIXTURES PARAMETERS DEVELOPMENT
}

\author{
Sergii Tsygankov \\ Institute of Food Biotechnology and Genomics NAS of Ukraine \\ 2A Osypovskoho str., Kyiv, Ukraine, 04123 \\ tsygankov.iht@gmail.com \\ Viktor Ushkarenko \\ Department of Agriculture \\ Kherson State Agricultural University \\ 23 Stretenskaya str., Kherson, Ukraine, 73000 \\ Ushkarenkov@gmail.com \\ Olena Grek \\ Department of milk and dairy products technology \\ National University of Food Technologies \\ 68 Volodymyrska str., Kyiv, Ukraine, 03680 \\ grek.nupt@gmail.com \\ Alla Tymchuk \\ Department of milk and dairy products technology \\ National University of Food Technologies \\ 68 Volodymyrska str., Kyiv, Ukraine, 03680 \\ 589112@ukr.net \\ Inna Popova \\ Department of Food Chemistry \\ National University of Food Technologies \\ 68 Volodymyrska str., Kyiv, Ukraine, 03680 \\ ivpopova@bigmir.net \\ Natalia Chepel \\ Department ofFood Technologies \\ Kyiv Cooperative Institute of Business and Law \\ 18 Lomonosova str., Kyiv, Ukraine, 03022 \\ natachepel25@gmail.com




\author{
Olena Onopriichuk \\ Department of milk and dairy products technology \\ National University of Food Technologies \\ 68 Volodymyrska str., Kyiv, Ukraine, 03680 \\ olena.onopriychuk@gmail.com
}

Oleksandr Savchenko

Department of technologies of meat, fish and marine products

National University of Life and Environmental Sciences of Ukraine

15 Heroiv Oborony str., Kyiv, Ukraine, 03041

63savchenko@gmail.com

\begin{abstract}
The aim of the work is to develop methods of investigating the influence of semolina and extruded semolina on quality and quantity parameters of mixtures with milk-protein concentrates in a cycle of freezing-defrost that allows to substantiate resource-saving in semi-products manufacturing.

Obtained results of changes of the quality of protein-vegetable mixtures after the effect of negative temperatures confirm cryo-protective properties of carbohydrates of products of wheat processing.

There were studied methods of extracting proteins of whey for getting albumin mass and using in the composition of milk-protein concentrates. It was established, that adding collagen-containing ingredients in amount $0,4 \%$ for intensifying thermal

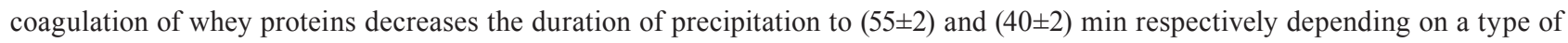
raw material processing. There were studied both native whey and protein concentrate, obtained by the method of ultra-filtration with mass share of dry substances $(16 \pm 2) \%$.

The method of thermal analysis determined a cryoscopic temperature of sour-milk fatless cheese and also albumin mass, obtained using «Collagen pro 4402». The calculation method, based on cryoscopic temperature indices determined an amount of moisture, frozen out in milk-whey mixtures with wheat processing products. The presented information is enough for estimating traditional modes of freezing milk-protein concentrates objectively.

The obtained results of the studies indicate the effectiveness of the offered methods for determining parameters of protein-vegetable mixtures after defrosting. Measurements of quality parameters may be used for correcting mass losses of concentrates effectively.

Keywords: products of grain processing, defrost, mil-protein mixtures, cryoscopic temperature, collagen-containing ingredient.
\end{abstract} Inna Popova, Natalia Chepel, Olena Onopriichuk, Oleksandr Savchenko

\title{
1. Introduction
}

Introduction of the technology of semi-products, based on milk-protein mixtures with vegetable components on the actual equipment, without technical re-equipment of an enterprise and establishment of special lines in production is expedient, because it doesn't need essential investments [1]. One of ways of providing stable quality and quantity parameters after defrosting milk raw materials is to make mixtures with products of grain processing at the freezing stage already [2].

A special place in prolonging storage terms of milk-protein concentrates (sour-milk cheese and albumin mass) belongs to methods of thermal processing: cooling, partial freezing and freezing. On the one hand, storage at negative temperatures causes changes of properties of a product, on the other - it provides a rather long storage term up to 12 months [3, 4].

Freezing is a process of leading heat away from a product, decreasing its temperature to one, essentially lower than cryscopic [5]. It is based on the principle of anabiosis - braking of the life activity of microorganisms and stopping of enzymatic processes in products, accompanied by crystallization of the most share of moisture. Moisture is frozen out of products completely at temperature $-(60 \ldots 70){ }^{\circ} \mathrm{C}$. In practice frozen products at temperature $-20{ }^{\circ} \mathrm{C}$ contain near $10 \%$ of unfrozen moisture [6]. After defrost milk-protein concentrates mainly save their initial properties, but lose mass [2]. Determination of a cryoscopic temperature of protein-vegetable mixtures and albumin mass with «Collagen pro 4402» may be used for correcting freezing conditions [7]. 
Ways of intensification of precipitation of the albumin mass of a whey concentrate, obtained by the method of ultrafiltration (WPCUF) need studying. The existing method [8] of determining the albumin output is general and appropriate for estimating the effectiveness of the process. Positive results favor the increase of production volumes of protein concentrates [1].

The topicality of producing semi-products, based on sour-milk cheese and albumin mass, favor realization of experimental studies for searching new technological solutions for saving the protein mass after defrost.

At choosing moisture-retaining component, there were selected grain processing products (GPP), included in recipes of semi-products, based on milk and protein.

According to the literary data [9], the effectiveness of vegetable ingredients, namely semolina, thermally processed, has increased structure-creating properties, comparing with native grain raw materials.

The main aim of extruding is to modify the carbohydrate complex at destructing factors, such as moisture and mechanical efforts. The complex effect of these factors conditions deeper destruction of chains of starch macromolecules [10].

At processing starch-containing raw materials in an extruder, the starch content decreases because of disintegration of molecules of amylase and amylopectin. It conditions the increase of solubility and swelling degree of extrudates comparing with raw materials without moisture-thermal processing [11].

After extrusion processing semolina that contains proteins and starch gets expressed plastic properties. At the temperature increase, there takes place reconstruction of polymeric structural forms and exothermal expansion of the mass [12].

Taking into account technological properties of extruded semolina with modified carbohydrate and protein complexes, it is possible to prognosticate the effectiveness of its use in the composition of protein-vegetable mixtures for freezing for decreasing losses at defrost.

The aim of the work is to determine the effectiveness of methods of investigating the influence of semolina and extruded semolina on decreasing losses of milk-protein mixtures at defrost that allows to substantiate resource-saving in semi-products manufacturing.

\section{Materials and Methods}

A raw material for the albumin mass and liquid whey protein concentrate (WPCUF) was cheese whey with the following physical-chemical parameters: mass share of dry substances $(6,1 \pm 0,3) \%$, including protein $(1,0 \pm 0,05) \%$, fat $(0,1 \pm 0,01) \%$, milk sugar $(4,5 \pm 0,2) \%$, mineral substances $(0,5 \pm 0,02) \%$, titrated acidity $(18 \pm 2){ }^{\circ} \mathrm{T}$, density $1018 \mathrm{~kg} / \mathrm{m}^{3}$.

«Collagen pro 4402»- a powder of a white- light creamy color that is partially dissolved in cold water and completely - at active mixing at temperature $(60 \ldots 65){ }^{\circ} \mathrm{C}$. The physical-chemical and microbiological parameters of «Collagen pro 4402» are presented in Table 1 [13].

Table 1

Physical-chemical and microbiological parameters of «Collagen pro 4402»

\begin{tabular}{lc}
\hline \multicolumn{1}{c}{ Parameter } & Content, $\%$ \\
\hline Protein & 50,0 \\
Hydrocoloid component, no less & 37 \\
Fat & 0,05 \\
Ashes & 5,0 \\
Moisture, no more & 7 \\
Active acidity of the solution pH, no more & 7 \\
Quantity of mesophilic aerobic and facultative-anaerobic microorganisms in 1 he, no more & $1 \cdot 10^{4}$ \\
Bacteria of the intestinal bacillus group (coliform), in 1 g & Not permitted \\
Pathogenic microorganisms, including salmonella, in 25 g & Not permitted
\end{tabular}


Wheat processing products (WPP), namely extruded semolina with water-retaining capacity in milk whey $(80 \pm 2) \%$ were used as a water binding ingredient [14].

The active acidity of milk whey was measured by the potentiometric method [15] on a universal ionometer of the model EZODO 7011 (Taiwan). The image of this device is presented on Fig. 1.

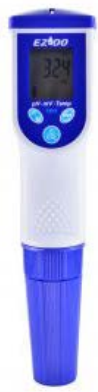

Fig. 1. pH-meter EZODO 7011

pH-meter has replaceable electrodes, is calibrated by three points $\mathrm{pH}-4,00,7,00$ and 10,00. A thermometer, installed in an electrode reflects a temperature on the screen and corrects $\mathrm{pH}$ value due to the automatic temperature compensation.

WPCUF was received in the laboratory of the National University of food technologies (Kiev, Ukraine) on an ultrafiltration setting (Fig. 2) with membranes of UPM 50 trademark [16]. The process conditions: diameter of pores $-15 \ldots 50 \mathrm{~nm}$, temperature $50{ }^{\circ} \mathrm{C}$, pressure $0,4 \mathrm{MPa}$. A raw material is cheese whey. The image of the membrane setting is presented on Fig. 2 .

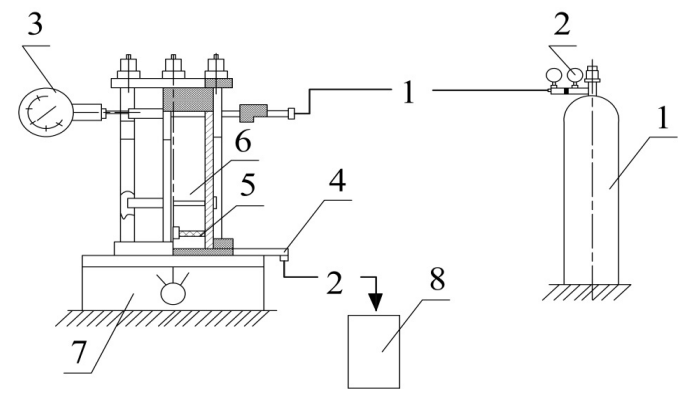

Fig. 2. Laboratory membrane setting of a standing type

The membrane setting of a standing type functions according to the following principle. Membrane (6) is laid in the lower part of a membrane chamber. It is pressed by a cylindric body that in its turn is placed between two metal disks. Both branch pipes must be open for pouring a working solution through one of them. Then one branch pipe is connected with high pressure balloon (1), and manometer (3) is fixed to the other. At switching magnetic mixer (7) on, milk whey begins to get mixed at the expanse of rotation in mixer's magnetic field (5). An obtained permeate is removed through branch pipe (4) in chamber (8). Pressure values in the chamber are regulated by redactor (2).

The obtained WPCUF has mass share of dry substances $(16 \pm 2) \%$. The parameter was determined by the refractometric method [15].

For thermal coagulation «Collagen pro 4402» [8] in amounts from $0,3 \%$ to $0,5 \%$ was added to WPCUF. The diapason is conditioned by recommendations of a producer that is $0,4 \%$. The process was conducted at temperature $(95 \pm 2)^{\circ} \mathrm{C}$. Such mode is classic for thermal precipitation of milk proteins.

Preparation of the collagen-containing ingredient provides hydromodule (supplement and whey in proportion 1:12) and heating. Realization of the aforesaid conditions is necessary because of the low solubility index of «Collagen pro $4402 »-1,6 \mathrm{~cm}^{3}$ a raw residue [15]. The hydromodule is introduced in cheese whey with temperature $90 \ldots 95^{\circ} \mathrm{C}$, mixed and thermally processed during 
$(90 \pm 2)$ min for creating albumin flakes. After finishing the coagulation process, cheese whey with the protein mass was filtered, and quantitative parameters of the albumin mass both of control and samples with different amounts of «Collagen pro 4402» were determined by weighing. A control is the albumin mass, obtained by classic technology [8] without the technological ingredient.

Taking into account maximal losses at defrost (comparing with other milk-protein concentrates) [17], for further studying in the process of storage at negative temperatures, there was selected fat-less sour-milk cheese with moisture mass share $(76,0 \pm 2) \%$.

Protein-vegetable mixtures (PVM) were prepared in the following succession. Sourmilk cheese and/or albumin mass were accurately mixed with wheat processing products in amount $6-7 \%$. The process was conducted during 3-5 min and briquettes with mass (200 \pm 2$) \mathrm{g}$ (size $90 \times 70 \times 30)$ were formed.

Freezing of all samples, packed in a polyethylene film, was realized in a freezing chamber SAMSUNG with a cooling agent R134a at temperature $-24 \pm 2{ }^{\circ} \mathrm{C}$.

Experimental samples were defrosted as following - briquettes were released from a film, laid on a filtrating paper. The process was conducted at temperature $(20 \pm 2){ }^{\circ} \mathrm{C}$, relative humidity of air $(80 \pm 2) \%$, speed of the air movement $0,1 \mathrm{~m} / \mathrm{s}$, till temperature $(0 \pm 2){ }^{\circ} \mathrm{C}$ (complete melting of ice crystals) within experimental samples.

There were realized determinations of a cryoscopic temperature of milk-protein mixtures with semolina (S) and extruded semolina (ES), provided in the freezing-defrost cycle.

A cryoscopic temperature of fatless sour-milk cheese and protein-vegetable mixtures (PVM) was determined by the method of thermal analysis, based on constructing curves of temperature changes of a product in time [18].

The temperature was registered and signed using the measuring complex. Developers are scientists of the department of thermal energetics and cooling techniques of the National University of food technologies (Kiev, Ukraine) [7]. The scheme of the complex is presented on Fig. 3.

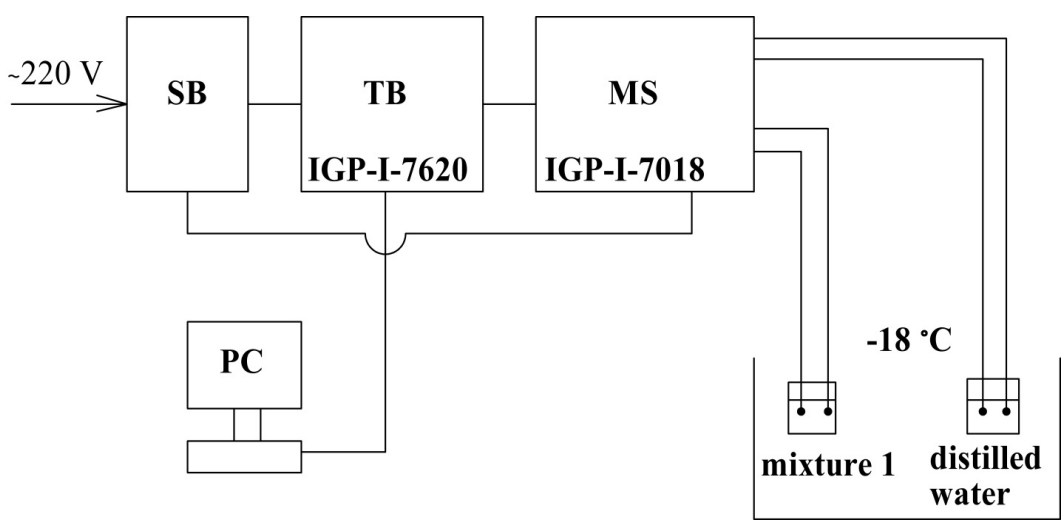

Fig. 3. Scheme of the experimental setting (SB - supplying block (from the circuit); TB - block of transforming standard RS-485 - RS-232; MB - measuring block with 8 thermocouples;

$\mathrm{PC}$ - registration of data (connection using RS-232 - USB); mixtures,

placed in the freezing chamber)

The complex includes a device for controlling the temperature with a set of copper-constant thermoelectric transformers (thermocouples) of $\mathrm{T}$ type with a measurement error no more 0,36\%, measuring block ICP i 7018 (Taiwan) and the block for transforming a signal ICP i7520 (Taiwan). Temperature values were realized using a computer by the program NDCONUTIL v.3xx (Ukraine). A relative amount of moisture, frozen out, is a ratio of an ice mass, formed in a product at given temperatures to the total mass of water, contained in a product, including solid and liquid phases [5].

Losses at defrosting milk-protein concentrates and PVM were determined equally - by the weighing method at stable conditions (external temperature; final temperature of defrost; duration) by the formula: 


$$
\mathrm{L}_{\mathrm{t}}=\left(1-\frac{\mathrm{T}_{1}}{\mathrm{~T}_{2}}\right) \times 100 \% \text {, }
$$

where $\mathrm{m}_{1}$ - mass of MPC or PVM after defrost, $\mathrm{g} ; \mathrm{m}_{2}-$ mass of MPC or PVM before freezing, $\mathrm{g}$.

The amount of moisture, frozen out, was determined by the simplified formula by R. Heis [19].

$$
\omega=\left(1+\frac{t_{\mathrm{cr}}}{t}\right) \times 100 \%
$$

where $\mathrm{t}$ - final temperature of a product, ${ }^{\circ} \mathrm{C} ; \mathrm{t}_{\mathrm{cr}}-$ cryoscopic temperature of a product, ${ }^{\circ} \mathrm{C}$

\section{Research results}

The results of the experimental studies of the albumin output (\%) from whey and WPCUF depending the amount of «Collagen pro 4402» (\%) at coagulation at temperature $90 \ldots 95{ }^{\circ} \mathrm{C}$, duration $(90 \pm 2)$ min are presented in Table 2. The process is conducted at $\mathrm{pH}$ of the environment $-4,6 \ldots 4,4$.

Table 2

Output of the albumin mass depending on the amount of «Collagen pro $4402 », \%$

\begin{tabular}{ccccccc}
\hline \multirow{2}{*}{ Raw material } & \multicolumn{7}{c}{ Amount of «Collagen pro 4402», \% } \\
\cline { 2 - 7 } & $\mathbf{0}$ & $\mathbf{0 , 3}$ & $\mathbf{0 , 3 5}$ & $\mathbf{0 , 4}$ & $\mathbf{0 , 4 5}$ & $\mathbf{0 , 5}$ \\
\hline Whey & $100,0 \pm 0,3$ & $102,1 \pm 0,2$ & $106,3 \pm 0,3$ & $125 \pm 0,1$ & $125,8 \pm 0,1$ & $126,1 \pm 0,2$ \\
WPCUF & $110,0 \pm 0,2$ & $112,5 \pm 0,1$ & $117,5 \pm 0,1$ & $140 \pm 0,3$ & $140,9 \pm 0,2$ & $141,3 \pm 0,1$
\end{tabular}

Percentage of the albumin mass output was corrected depending on the amount of dry substances of the introduced collagen-containing ingredient.

According to the results, introduction $0,4 \%$ of «Collagen pro 4402 » increases the albumin mass output of both whey and WPCUF in average by $25 \%$ at equal conditions of thermal coagulation.

In the technology of AM, obtained from «Collagen pro 4402», time of precipitation from whey is $(40 \pm 2) \mathrm{min}$, from a protein concentrate - $(30 \pm 2)$ min respectively. The duration of thermal processing of samples decreased by $(15 \pm 1) \mathrm{min}$.

There was studied the influence of the amount semolina and extruded semolina, introduced in sour-milk cheese and albumin mass, on the cryoscopic temperature of mixtures. The results are important for determining moisture losses and their decrease.

According to the results, the cryoscopic temperature of AM with the collagen-containing ingredient is $-0,6{ }^{\circ} \mathrm{C}$. This index for the control is $-0,3{ }^{\circ} \mathrm{C}$. The analysis of the obtained data testifies that introduction of «Collagen pro 4402» at thermal coagulation increases the amount of water, not transformed in ice at freezing.

The cryoscopic temperature of sour-milk cheese was $-0,74^{\circ} \mathrm{C}$; for samples with $\mathrm{S}$ in amount $6 \%$ and $7 \%--1,01{ }^{\circ} \mathrm{C}$ and $-1,14{ }^{\circ} \mathrm{C}$ respectively. For samples with ES in the aforementioned amounts, the index was fixed at level $-1,76^{\circ} \mathrm{C}$ and $-1,82{ }^{\circ} \mathrm{C}$.

The low value of the cryoscopic temperature for sour-milk cheese and the highest one for protein mixtures with ES in amount $7 \%$ prove the theory of the influence of GPP carbohydrates on the moisture condition.

Based on the cryoscopic temperature, there was calculated the amount of frozen out PVM moisture in $\%$ that is 88,75 for the control sample (SMC). This index for samples with adding $\mathrm{S}$ in amounts 6 and $7 \%$ was 86,61\% and 85,54\%,and for ES 80,12\% and 79,37\% respectively.

Quantitative losses of PVM with different amounts (from 5 to $8 \%$ ) of S and ES at defrost are presented in Table 3 . 
Table 3

Losses at defrosting PVM mass with different amounts of S and ES, \%

\begin{tabular}{lcccc} 
& \multicolumn{4}{c}{ Amount of introduced GPP, $\%$} \\
\cline { 2 - 4 } Raw material & $\mathbf{5}$ & $\mathbf{6}$ & $\mathbf{7}$ & $\mathbf{8}$ \\
PVM with S & $7,85 \pm 0,1$ & $7,70 \pm 0,15$ & $7,30 \pm 0,2$ & $7,00 \pm 0,1$ \\
PVM with S & $7,30 \pm 0,2$ & $6,00 \pm 0,1$ & $5,50 \pm 0,15$ & $4,50 \pm 0,2$
\end{tabular}

Thus, at introducing $\mathrm{S}$ to the protein base, mass losses vary within $7,8 \ldots 6,9 \%$. The least percent of losses is observed at introducing ES and is 7,31...4,47\%. The control in the studies is fatless sour-milk cheese with moisture mass share $-76,0 \%$, titrated acidity $-206^{\circ} \mathrm{T}$. Mass losses of the control at defrost were $(9,0 \pm 0,4) \%$, that is by $4,5 \%$ more than in PVM. The limiting factor is an amount of GPP in recipes of semi-products, providing the use of PVM [2].

Separation of moisture was fixed in 2 hours of defrost, and the end in 3,5 hours. $15,2 \%$ of moisture was extracted from AM sample, obtained after adding «Collagen pro 4402», and from a sample, produced by the classic technology $-20,5 \%$. It is probably connected with an ability of the collagen-containing ingredient to prevent dispersing of coagulated albumin that favors flakes concentration. Such technical hold provides preservation of quantity indices after reaching temperature $0{ }^{\circ} \mathrm{C}$ within samples.

\section{Conclusions}

The effective methods of studying intensification of the process of thermoacid coagulation of whey proteins with WPCUF at «Collagen pro 4402» were established. The time of coagulation of WPCUF proteins with mass share of dry substances $(16 \pm 2) \%$ at temperature $92 \ldots 95{ }^{\circ} \mathrm{C}$ decreased by $10 \mathrm{~min}$, comparing with the control. An advantage of this study is a possibility of realizing the technology on the actual equipment at traditional temperatures. A shortcoming of the offered method is a necessity of concentrating whey proteins and costs for the technological ingredient- «Collagen pro 4402».

There was determined the cryoscopic temperature that is $-1,01{ }^{\circ} \mathrm{C}$ and $-1,14{ }^{\circ} \mathrm{C}$ for PVM with S (6\% and $7 \%$ ), and for PVM with ES with the aforesaid amounts $-1,76{ }^{\circ} \mathrm{C}$ and $-1,82{ }^{\circ} \mathrm{C}$ respectively. The highest cryoscopic temperature was fixed for sour-milk cheese (control) and the lowest for PVM with ES in amount $7 \%$. The measuring method allows to estimate the cryoprotective effect of carbohydrates of semolina excudate objectively. The increase of the amount of ES from 6 to $7 \%$ decreases the amount of moisture, frozen out, by $0,75 \%$ at temperature $-25^{\circ} \mathrm{C}$, that is important for saving native properties of PVM proteins. The results indicate objective possibilities for the effective functioning in production systems. Probably it will provide the decrease of losses at defrost at te expanse of decreasing the amount of moisture, frozen away.

The presented information is recommended to be used for substantiating resource saving at manufacturing semi-products, based on defrosted milk-protein concentrates.

A limiting factor for continuing studies in this direction is the absence of choice of vegetable components in recipes of traditional semi-products.

\section{References}

[1] Butenko, M. I. (2014). Monitorynh rozvytku rynku moloka ta molochnykh produktiv Ukrainy. Molochna promyslovist, 3, 24-30.

[2] Hrek, O. V., Onopriychuk, O. O., Tymchuk, A. V. (2014). Mathematical modeling of parameters of albumin- vegetable mixtures after unfreezing. Prodovolcha industriya APK, 2, 15-18.

[3] Kljajevic, N. V. (2017). Textural and physico-chemical characteristics of white brined goat cheeses made from frozen milk and curd. The use of square I - distance statistics. Mljekarstvo, 130-137. doi: https://doi.org/10.15567/mljekarstvo.2017.0205

[4] Gnitsevych, V., Yudina, T., Deinychenko, L., Nykyforov, R., Nazarenko, I. (2018). Definition of quality indicators of dairy-protein concentrates in the storage process. EUREKA: Life Sciences, 1, 10-17. doi: https://doi.org/10.21303/2504-5695.2018.00526 
[5] Maslikov, M. M. (2007). Kholodylna tekhnolohiya kharchovykh produktiv. Kyiv: NUKhT, 335.

[6] Gnytsevych, V., Yudina, T., Deinychenko, L., Nykyforov, R., Nazarenko, I. (2018). Survey of characteristics of dairy-protein concentrates in the low-temperature storage process. Eastern-European Journal of Enterprise Technologies, 1 (11 (91)), 16-21. doi: https://doi.org/10.15587/1729-4061.2018.120749

[7] Zviahintseva-Semenets, Yu. P., Kolodzynskyi, R. I., Maslikov, M. M. et. al. (2017). Cryoskopic temperature of reduced fatty cream. Internauka, 18.

[8] Grek, E. V., Timchuk, A. V. (2013). Intensification of denaturation of whey proteins. Maisto chemija ir technologija. Mokslo darbai (Food chemistry and technology. Proceedings). Kauno tecnologijos universiteto maisto institutas. Kaunas, 47 (2), 23-31.

[9] Onopriychuk, O. O., Hrek, O. V. (2012). Syrkovi pasty iz zernovymy inhrediientamy. Prodovolcha industriya APK, 4, 35-38.

[10] Ibrahim, A. A., Abd-Ellati, A. R. M., Ragab, G. H. (2016). Production of some Snack Foods by Extrusion Processing of some Cereals and their By-products. American Journal of Food Technology, 12 (1), 66-71. doi: https://doi.org/10.3923/ajft.2017.66.71

[11] Satusap, P., Chavasit, V., Kriengsinyos, W., Judprasong, K. (2014). Development of cereal and legume based food products for the elderly. SpringerPlus, 3 (1), 451. doi: https://doi.org/10.1186/21931801-3-451

[12] Đurđica, Ačkar, Jozinović, A., Šubarić, D. et al. (2014). Influence of semolina moisture content on extrudate properties. Glasnik zaštite bilja, 4, 66-69.

[13] Pishchevye dobavki dlya molochnyh produktov: obzor i osobennosti. Available at: https://kherson-news.net/blogi/biznes-i-rabota/item/5850-pishchevye-dobavki-dlya-molochnykh-produktov-obzor-iosobennosti.html

[14] Baluyan, H. A., Malkina, V. D., Zhirkova, E. V. et. al. (2016). Vliyanie biologicheski aktivnyh ekstruzionnyh ingredientov na hlebopekarnye i reologicheskie svoystva pshenichnoy muki. Hleboprodukty, 7, 48-51.

[15] Hrek, O. V., Yushchenko, N. M., Osmak, T. H. et. al. (2015). Praktykum z tekhnolohiyi moloka ta molochnykh produktiv. Kyiv: NUKhT, 431.

[16] Myronchuk, V. G., Grushevskaya, I. O., Kucheruk, D. D., Zmievskii, Y. G. (2013). Experimental study of the effect of high pressure on the efficiency of whey nanofiltration process using an OPMN-P membrane. Petroleum Chemistry, 53 (7), 439-443. doi: https://doi.org/10.1134/s0965544113070116

[17] OOO «Mona Ingredients». Tvorozhniy produkt special'nogo naznacheniya (2017). Molochnaya reka, 4 (68), 56-58.

[18] Dobrovol'skaya, A. V., Shamkova, N. T., Hrisonidi, V. A. (2015). Issledovaniya fazovyh perekhodov kombinirovannyh mass na osnove tvoroga metodom differencial'no-termicheskogo analiza. Izvestiya vuzov. Pishchevaya tekhnologiya, 5-6, 97-101.

[19] Korotkiy, I., Korotkaya, E. (2008). Opredelenie temperatury zamerzaniya plodov oblipihi. Hranenie i pererabotka sel'zkhozsyr'ya, 1, 24-25. 